\title{
Transnacionāla krāpšana: starptautiskās tiesiskās sadarbības modernizācijas problēmas
}

\author{
Kristine Ārensone \\ Rīgas Stradiña universitāte, Latvija \\ kristine.arensone@gmail.com
}

\section{Kopsavilkums}

Starptautiskā tiesiskā sadarbība ar ārvalstu izmeklēšanas iestādēm ir ḷoti svarīga, un jebkuras tās formas, arī ārvalstīs esošo liecinieku pratināšana un nepieciešamās informācijas iegūšana, palīdz ātrāk novest kriminālprocesu līdz tiesai. Pat ja Latvijā ir visas nepieciešamās datubāzes un visas iespējas iegūt informāciju, bez starptautiskās tiesiskās sadarbības ārvalstīs nevarētu atrast un nopratināt konkrētās personas un uzlikt arestu to bankas kontiem.

N̦emot vērā pašreizējās ekonomiskās problēmas gan Eiropā, gan citviet pasaulē, ir nepieciešams spēcīgāks publisko izdevumu pamatojums un izlietojuma pārskatāmība. Dalībvalstu pilsoni no Eiropas Savienības gaida būtisku rīcību un palīdzību, lai dalībvalstis varētu aizsargāt savu likumīgo ekonomiku pret organizēto noziedzību, krāpšanu finanšu un nodokḷu jomā, nelikumīgi iegūtu līdzekḷu legalizēšanu un korupciju. Lietās par pārrobežu krāpšanu ir nepieciešama koordinēta un efektīva Eiropas līmeña izmeklēšana un kriminālvajāšana. Kaut gan Eirojust, Eiropols un Eiropas Birojs krāpšanas apkarošanai (OLAF), kā arī citas struktūras cenšas strādāt ar šo jautājumu pastiprināti, tomēr pašreizējais informācijas apmaiņas un koordinācijas līmenis nav pietiekams, lai šo mērḳi sasniegtu.

Atslēgvārdi: krāpšana, korupcija, Eiropas Savienība, tiesiskā sadarbība.

\section{levads}

Krāpšana nodara lielu kaitējumu ekonomikai un sabiedrībai kopumā. Daudzas pasaules valstis cieš no dziḷi iesakṇojušās krāpšanas un korupcijas, kas traucē ekonomikas attīstībai, grauj demokrātiju un nodara kaitējumu sociālajam taisnīgumam un tiesiskumam. Arī Eiropas Savienības dalībvalstis nav no tās pasargātas. Krāpšana katrā 
valstī izpaužas atšķirīgi pēc veida un apmēra, taču tā skar visas dalībvalstis un apdraud labu pārvaldību, publisko finanšu pareizu pārvaldību un tirgus konkurētspēju.

Saskañā ar Eiropas Savienības Pretkorupcijas ziṇojumu krāpšana un korupcija vien Eiropas Savienības ekonomikai izmaksā 120 miljardus eiro gadā, kas ir tikai nedaudz mazāk par Eiropas Parlamenta apstiprināto Eiropas Savienības 2017. gada budžetu 158 miljardiem eiro.

Eiropas Savienības valstu iestādes veic izmeklēšanu un kriminālvajāšanu krāpšanas lietās, kas skar Eiropas Savienības finanšu intereses, bet to pilnvaras ir spēkā tikai attiecīgajā valstī. Noziedzīgi nodarījumi, kas skar Eiropas Savienības finanšu intereses, bieži vien ir komplicēti. Tie ietver vairākus dalībniekus, sarežğìtas un niansēti izstrādātas krāpšanas shēmas, vairākas valstis un vairāku valstu jurisdikcijas. Lietās par pārrobežu krāpšanu ir nepieciešama koordinēta un efektīva Eiropas līmeṇa izmeklēšana un kriminālvajāšana, tomēr pašreizējais Eirojust, Eiropola un Eiropas biroja krāpšanas apkarošanai un citu struktūru informācijas apmaiṇas un koordinācijas līmenis nav pietiekams, lai šo mērḳi sasniegtu.

Raksta mērḳis ir aplūkot pārrobežu sadarbības lomu krāpšanas un korupcijas mazināšanā Eiropas Savienībā, kā arī novērtēt ekstrateritoriālus noteikumus, likumus, lai sauktu pie atbildības jebkuru uzṇēmumu vai asociētu personu ne tikai likuma izdevēja valstī, bet arī ārvalstīs. Kā piemērs apskatīts Apvienotās Karalistes Likums par kukuḷošanu (UK Bribery Act). Aplūkotas arī starptautiskās tiesiskās sadarbības modernizācijas problēmas un tiesiskie risinājumi krāpšanas mazināšanai Eiropas Savienībā. Rakstā analizēti Latvijas Republikas un Eiropas Savienības normatīvie akti, kas nosaka krāpšanas novēršanas tiesisko pienākumu.

Darbā izmantota analītiskā un aprakstošā pētniecības metode. Lai noteiktu, kādi faktori ietekmē krāpšanas apkarošanu Eiropas Savienībā, izmantota indukcija un dedukcija.

\section{Pārrobežu sadarbības loma krāpšanas un korupcijas apkarošanā}

Saskan̄ā ar Eiropas Komisijas 2016. gada 17. jūlija ziņojumu Eiropas Savienības dalībvalstis, kas efektīvi vēršas pret krāpšanu un korupciju savā valstī, bieži saskaras ar problēmām saistībā ar savu uzṇēmumu rīcību ārvalstīs, îpaši valstīs, kur koruptīvas darbības ir plaši izplatītas [8].

Pēdējā laikā globalizācijas, jauno informācijas un komunikāciju tehnolog̣iju, kā arī citu faktoru dēḷ parādās arvien vairāk gadījumu, kad noziedzīgi nodarījumi tiek izdarīti uzreiz vairākās valstīs. It îpaši tas attiecināms uz korupciju un noziedzịgi iegūtu līdzekḷu legalizāciju, kad krāpšanas shēmas tiek îstenotas vairākās valstīs.

Krāpšana apdraud gan valstu ekonomisko, sociālo un tiesisko attīstību, gan ikviena šo valstu iedzīvotāja tiesību un brīvību realizāciju, tādējādi mazinot sabiedrības lojalitāti pret savu valsti un ietekmējot valsts politisko stabilitāti [17]. 
Starptautiskā sadarbība kriminālnoziegumu kontrolē ir viena no starptautisko attiecību un valstu sadarbības specifiskajām jomām. Tas ir nepieciešams nosacỉjums un lìdzeklis, lai nostiprinātu un garantētu tiesisko kārtību un likumību, cilvēka tiesības gan nacionālā, gan starptautiskā līmenī [12, 60].

Kriminālvajāšana par noziedzīgiem nodarījumiem pret Eiropas Savienības budžetu šobrīd ir tikai un vienīgi dalībvalstu kompetencē, un šajā jomā nav izveidota neviena Eiropas Savienības iestāde. Lai arī šo noziedzīgo nodarījumu iespējamais kaitējums ir l̦oti nozīmīgs, attiecīgo valstu iestādes ne vienmēr tos izmeklē un uzsāk kriminālvajāšanu, jo to tiesībaizsardzības resursi ir ierobežoti. Iznākumā attiecīgo valstu tiesībaizsardzības centieni šajā jomā joprojām bieži vien ir sadrumstaloti, turklāt šo noziedzīgo nodarījumu pārrobežu dimensiju atbildīgās iestādes parasti neievēro.

Iestādēm, kuras pieder pie dažādām teritoriālajām un funkcionālajām piekritībām, ir dalìta atbildība, tāpēc ir daudz problēmu un ierobežojumu saistībā ar koordināciju, sadarbību un informācijas apmaiṇu. Nepilnības tiesas iestāžu rīcībā, vēršoties pret krāpšanu un korupciju, ir novērojamas dažādos līmeņos un starp dažādām iestādēm, kā arī ir galvenais škēêrslis efektīvai izmeklēšanai un saukšanai pie atbildības par noziedzīgiem nodarījumiem, kas apdraud Eiropas Savienības finansiālās intereses.

Ekonomiskās sadarbības un attīstības organizācija (ESAO) veic stingru uzraudzību šajā jomā un savos regulārajos vērtējumos izcel gan labos, gan mazāk apmierinošus noteikumu izpildes rezultātus. Vairākās Eiropas Savienības dalībvalstīs ir labas prakses piemēri - noziedznieki tiek sekmīgi saukti pie atbildības, turklāt sankcijas ir būtiski augušas un norit augstā līmenī, par prioritāti nosakot ārvalstu kukuḷsšanas lietas, un nesen pieṇemts visaptverošs tiesību akts kukuḷošanas jomā, ar kuru tiek stiprināti tiesiskie un procesuālie rīki korupcijas, īpaši ārvalstu, un kukuḷošanas novēršanai un saukšanai pie atbildibas par to [8].

Krāpšanas un korupcijas transnacionālais raksturs uzskatāmi attēlots kartē (sk. att.).

Daži likumi, piemēram, ASV likums par korupciju saistībā ar ārvalstīm (U.S. Foreign Corrupt Practices Act (FCPA)), attiecas uz visām valstīm, kurās uzṇēmums veic uzṇēmējdarbību. Lai gan katrā valstī pretkorupcijas tiesību akti atšķiras, tomēr lielākā dą̣a no tiem nosaka aizliegumus veikt neatbilstīgus maksājumus, lai iegūtu vai saglabātu uzṇēmējdarbību. Kukuḷdošana valsts amatpersonām visās valstīs ir pretlikumīga.

Viens no labās prakses piemēriem, kā vērsties pret iekšzemes un ārvalstu kukuḷošanu, noteikti ir Apvienotās Karalistes likums par kukuḷošanu (UK Bribery Act).

Pateicoties 2010. gada Apvienotās Karalistes likumam par kukuḷošanu, kurš stājās spēkā 2011. gada 1. jūlijā, Apvienotajai Karalistei pašlaik ir vieni no stingrākajiem noteikumiem pasaulē cinnai pret kukulıšanu. Minētais likums paredz kriminālatbildību ne vien personām par kukuḷdošanu un kukuḷnemšanu un ārvalstu amatpersonu piekukuḷošanu, bet arī komerciālām organizācijām, kuras nenovērš kukuḷošanu, kas izdarīta to vārdā $[16,15]$. 


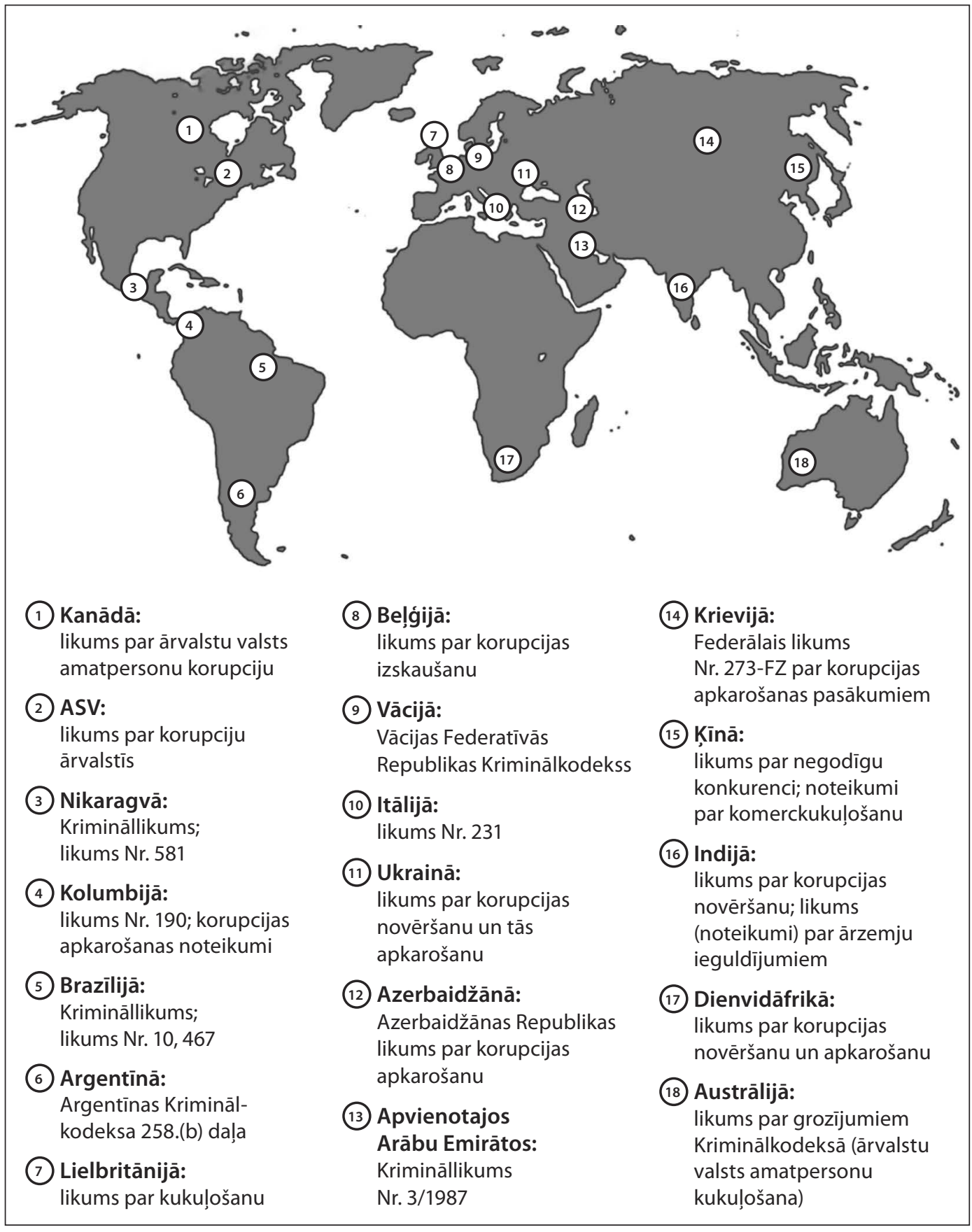

Attēls. Krāpšanas un korupcijas transnacionālais raksturs [14] 
Noteikumi par ekstrateritoriālu jurisdikciju l̦auj Liela apmēra krāpšanu apkarošanas birojam (The Serious Fraud Office - SFO) saukt pie atbildỉbas jebkuru uzñēmumu vai sadarbības partneri, kurš atrodas Apvienotajā Karalistē, pat tad, ja uzñēmums ir bāzēts ārvalstīs. Komerciālās organizācijas tiek atbrīvotas no kriminālatbildības, ja tām bijušas atbilstīgas procedūras kukuḷošanas novēršanai.

SFO Norādījumos komerciālām organizācijām (Guidance to Commercial Organisations - GCO) tiek veicināta izpratne par jauno tiesisko regulējumu un sniegti praktiski norādījumi uzṇēmumiem (tostarp, izmantojot gadỉjumu izpēti) par likumā paredzētajiem to pienākumiem novērst vai atklāt kukul̦ošanu. Saskaṇā ar iepriekšēju ESAO ieteikumu GCO skaidri norāda, ka veicināšanas maksājumi ir uzskatāmi par nelikumīgiem kukul̦iem, un sniedz uzṇēmumiem kritērijus, kā atškịt devīgumu no slēpta kukuḷšanas veida [7].

SFO ir plašas pilnvaras veikt izmeklēšanu un saukt pie atbildības saistībā ar liela apmēra un sarežgìtu krāpšanu, tostarp korupciju. Noteiktos apstākḷos SFO var izskatīt līdzekḷu piedziņas rīkojumus civilprocesos un izlīgumus saskaņā ar iepriekšējām pamatnostādnēm.

Ekonomiskās sadarbības un attīstības organizācija ir kritizējusi Eiropas Savienības dalībvalstis par to, ka saukšana pie atbildības ārvalstu kukuḷošanas lietās tiek veikta nepietiekami vai netiek veikta vispār, n,emot vērā korupcijas riskus, ar kādiem to uznēēmumiem jāsaskaras ārvalstīs.

Tiesībaizsardzības un prokuratūras iestāžu efektivitāte korupcijas izmeklēšanā Eiropas Savienības dalībvalstīs ir ḷoti atšḳirīga. To efektivitātes izvērtēšanā vērā n̦emtie faktori ietver korupcijas lēsto apmēru un būtību, ar kādu tām jāsaskaras, samēru ar novēršanas pasākumiem, politisko gribu atbalstìt to neatkarību, to rīcībā esošās spējas un resursus, potenciālos šḳēršḷus izmeklēšanai, tiesu iestāžu efektivitāti, jo īpaši to neatkarību, u.c. Novērtējumu veikt ir grūti, jo korupcijas noziegumu statistika vairumā dalïbvalstu nav konsekventa. Tikpat kā nav aktuālas, precīzas, konsolidētas statistikas par visiem korupcijas lietu procesuālajiem posmiem [7]. Lai efektīvi vērstos pret korupciju, ar represīviem pasākumiem vien nepietiek. Tomēr tam, ka tiesu sistēma spēj piemērot kriminālsankcijas, kas attur no korupcijas, ir būtiska loma, un tā ir skaidra zīme, ka korupcija netiek pieciesta.

Dažas dalībvalstis liek īpašu uzsvaru uz represīvo aspektu, un tiesībaizsardzība kḷusst par pretkorupcijas pasākumu galveno izpausmi. Teicamus rezultātus var vērot arī dalībvalstīs, kurās prokuratūra kopumā (ietverot ne tikai dienestus, kas specializējušies korupcijā) ir efektīva. Dažās citās dalībvalstīs saukšana pie atbildības ir sekmīga pārāk maz gadījumos vai arī izmeklēšana ir ilga [7].

Tiesu sistēmas neatkarība ir pretkorupcijas politikas būtisks elements, raugoties no tiesu sistēmas spējas efektīivi risināt korupcijas, tostarp augsta līmeņa korupcijas, lietas, kā arī no integritātes standartiem pašā tiesu sistēmā. Efektīvi neatkarības aizsardzības pasākumi un augsti ētikas standarti tiesu iestāžu sistēmā ir būtiski, lai nodrošinātu 
nepieciešamo satvaru efektīvai tiesu sistēmai, kas korupcijas lietās tiesu spriež objektīvi un taisnīgi bez nepamatotas iejaukšanās [7].

Eiropas Komisijas 2016. gada 14. jūlija Pretkorupcijas ziṇojumā tiesībaizsardzības un prokuratūras iestāžu neatkarība ir norādīta kā problēma dažās dalībvalstīs, nespriežot par vispārējo institucionālo struktūru, kas atspoguḷo katras dalībvalsts konstitucionālo, tiesisko un kultūras vidi un uz ko attiecas atsevišḳi mehānismi un procedūras Eiropas Savienības līmenī. Dažos gadỉjumos ir paustas bažas par politisku iejaukšanos prokuratūras dienestu un tiesu darbā korupcijas lietās. Kā piemērus var minēt procedūru nepārredzamu vai diskrecionāru piemērošanu galveno prokuroru, kuri strādā ar korupcijas lietām, iecelšanā, amata virzībā vai atstādināšanā no amata, kā arī pretkorupcijas iestāžu vai to vadītāju atlaišanu vai mēginājumus tos diskreditēt bez acīmredzama objektīva iemesla. Citos gadījumos pretkorupcijas tiesībaizsardzības ag̉entūras ir pieredzējušas, ka to pārvaldībā un darbībā iejaucas politiskas personas. Dažu pretkorupcijas institūciju plašajām pilnvarām ne vienmēr atbilst attiecīga atbildība, tādēl var rasties iespaids, ka tās varētu izvairīties no augsta profila lietām vai izmantot pretrunīgas izmeklēšanas metodes [8].

Nav vienotu standartu, kas noteiktu tiesībaizsardzības vai prokuratūras dienestu vadītāju iecelšanas vai atstādināšanas no amata procedūru. Šãdi lēmumi vairumā dalībvalstu ir valdības ziṇā kā politiskās atbildības izpausme un atspoguḷo tiesībaizsardzības un prokuratūras vietu izpildvarā. Neraugoties uz to, kāda procedūra tiek izmantota, procesam jābūt ticamam un balstîtam uz sasniegumiem, lai nepiel̦autu, ka rodas iespaids par politisku ietekmi, un lai policija un prokuratūra varētu izmeklēt korupciju ikreiz, kad to atklāj. Tika norādīts, ka dažās dalībvalstīs trūkst arī efektīvas koordinācijas starp tiesībaizsardzības un pretkorupcijas agentūrām.

Eiropas Komisijas pretkorupcijas ziṇojumā tiek paustas bažas par tiesu iestāžu integritāti darbā ar korupcijas lietām un par to neatkarību vai integritāti, par ko liecina to korupcijas lietu apmērs un būtība, kurās iesaistīti tiesneši vai prokurori. Vienā dalībvalstī izveidotā specializētā pretkorupcijas tiesa ir saskārusies ar būtiskām problēmām (un pat uz laiku pārtraukusi darbību), kas ietekmēja tās stabilitāti un spējas sasniegt pārliecinošus rezultātus [8].

Ja ir aizdomas par noziedzīgiem nodarījumiem saistībā ar ES fondiem, valsts līmenī bieži ir nepietiekama informācijas apmaiṇa starp iestādēm, kas atbildīgas par uzraudzību un kontroli, administratīvās izmeklēšanas iestādēm un tiesībaizsardzības iestādēm. Tas daḷēji rodas iepriekš minēto procedūru nepilnību dēl un kavē efektīvu daudznozaru izmeklēšanu, iesaistot dalībvalstu tiesu, administratīvās, muitas un nodokḷu iestādes. Ağentūras, kas pārvalda un kontrolē ES līdzekḷu izmaksu, dažkārt koncentrējas vienīgi uz savu līdzekḷu atgūšanu, izmantojot administratīvas un civiltiesību procedūras. Arī gadījumā, kad pastāv pamatotas aizdomas, ka ir noticis noziedzīgs nodarījums, var netikt uzsākta kriminālvajāšana [8]. 


\section{Eiropas Tiesiskās sadarbības tīkls krimināllietās}

Eiropas Tiesiskās sadarbības tīkls (ETST) krimināllietās, kas izveidots 1997. gadā, ir dalībvalstu kontaktpunktu tīkls. Kontaktpunkti ir izvēlēti no tieslietu vai citām iestādēm, kam ir konkrēti pienākumi starptautiskās tiesiskās sadarbības jomā. ETST mērḳis ir uzlabot tiesisko sadarbību starp Eiropas Savienības dalībvalstīm juridiskā un praktiskā ziṇā, lai apkarotu smagus noziegumus, it ìpaši organizēto noziedzību, korupciju, narkotiku kontrabandu un terorismu.

ETST krimināllietās darbība ir vērsta uz informācijas un viedokḷu apmaiṇu starp Eiropas Savienības dalībvalstīm krimināltiesiskās sadarbības ietvaros, kā arī tiešu kontaktu dibināšanu starp Eiropas Savienības dalībvalstu kompetento institūciju amatpersonām. Eiropas tiesiskā tīkla darbība nodrošina efektīvu tiesiskās palīdzības lūgumu nosūtǐšanu un izpildi. ETST sniedz ieskatu par Eiropas Savienības dalïbvalstu likumdošanu saistībā ar Eiropas Savienības dokumentu ieviešanu katrā dalībvalstī. Latvijas Republikas Tieslietu ministrija minētajā tīklā veic korespondenta funkcijas. Korespondenta loma ir sniegt informāciju par Latvijas dalību tiesiskajā sadarbībā krimināllietās un viedokli par tiesiskās sadarbības aktuālākajiem jautājumiem, kā arī palīdzỉbu citu valstu kontaktpunktiem un korespondentiem par kārtību, kā Latvijā tiek realizēta tiesiskā sadarbiba [9].

ETST krimināllietās pamatprincips ir vienkāršs - katrā dalībvalstī noteikt atbildīgās personas, kas veic svarīgus praktiskus uzdevumus tiesiskās sadarbības jomā krimināllietās, lai varētu izveidot speciālistu tīklu un nodrošinātu savstarpējas juridiskas palīdzības lūgumu pienācīgu izpildi. Eiropas Tiesiskās sadarbības tīkls iegūst īpašu nozīmi tāpēc, ka piemēro principu, kas paredz tiešus kontaktus starp kompetentajām tiesu iestādēm [9].

ETST sastāv no dalībvalstu un Eiropas Komisijas kontaktpunktiem. Katra dalïbvalsts par valsts kontaktpunktu iecel kādu no galvenajām iestādēm, kas atbild par starptautisko tiesisko sadarbību, tiesu iestādēm un citām kompetentajām iestādēm, kam ir konkrēti pienākumi starptautiskās tiesiskās sadarbības jomā gan jautājumā par smagiem noziegumiem, gan jautājumā par konkrētiem smagu noziegumu veidiem, piemēram, organizēto noziedzību, korupciju, narkotiku kontrabandu vai terorismu [9].

ETST krimināllietās no Latvijas puses pārstāv Tieslietu ministrija kopā ar G̣enerālprokuratūru. Kontaktpunkti ir aktīvi starpnieki, kuru uzdevums ir atvieglot dalībvalstu tiesisko sadarbību, it īpaši cinnā pret dažāda veida smagiem noziegumiem. Padomes lēmumā par Eiropas Tiesiskās sadarbības tīklu teikts, ka kontaktpunkti dos iespēju vietējām kompetentajām iestādēm "izveidot vispiemērotākos tiešos kontaktus" [9].

Tādējādi kontaktpunkti sniedz juridisku un praktisku informāciju, kas nepieciešama vietējām iestādēm, lai efektīvi sagatavotu tiesiskās sadarbības lūgumus, kā arī veic koordinatoru funkcijas gadījumos, ja vienā dalībvalstī vietējās tiesu iestādes iesniedz vairākus lūgumus, kas prasa koordinētu rīcību citā Eiropas Savienības dalībvalstī. 


\section{Tiesiskie risinājumi starptautiskās tiesiskās sadarbības modernizācijai un krāpšanas mazināšanai Eiropas Savienībā}

Efektīvu izmeklēšanu un kriminālvajāšanu par noziedzīgiem nodarījumiem pret ES finansiālajām interesēm kavē fakts, ka tiesībaizsardzības iestādes un prokurori ne vienmēr nodod informāciju par noziedzīgiem nodarījumiem saviem kolēgiem citās dalībvalstīs, kā arī Eirojust vai Eiropolam. Turklāt klasiskie starptautiskās sadarbības veidi, izmantojot savstarpējās tiesiskās palīdzības pieprasījumu vai kopējās izmeklēšanas grupas, bieži vien nedarbojas pietiekami labi, lai šos noziedzīgos nodarījumus efektīvi izmeklētu un veiktu pilnvērtīgu kriminālvajāšanu. Dažkārt nelīdz pat Eirojust un Eiropols. Atbildes uz tiesiskās palīdzības lūgumiem bieži tiek saṇemtas pēc ilga laika, un policijas un tiesu iestādes izjūt praktiskas grūtības saziṇā un sadarbībā ar kolēǵiem ārzemēs valodas problēmu un atškịingo tiesību sistēmu dēḷ. Dažās valstīs lēna un neefektīva starptautiskā sadarbība bieži ir izraisījusi nespēju turpināt lietas izskatīšanu noilguma termiṇa izbeigšanās dēḷ. Turklāt gadījumi, kas skar ES finansiālās intereses, ir īpaši sarežǵīti [5].

Eirojust un Eiropols ne vienmēr saṇem vajadzīgo informāciju, lai varētu atbalstīt dalībvalstis. OLAF sniedz atbalstu dalībvalstīm, izmantojot savu spēju piedāvāt speciālo tehnisko un operatīvo palīdzību, kā paredzēts Konvencijas par Eiropas Kopienu finanšu interešu aizsardzību Otrā protokola 7. pantā. Tajā pašā laikā OLAF izmeklēšanas darbības veic saskaṇā ar konkrētiem nosacījumiem, jo īpaši, kad ir runa par informācijas nosūtīšanu valstu tiesu iestādēm, tostarp ievērojot datu aizsardzības noteikumus. Šā iemesla dēḷ sadarbība ar OLAF dažkārt tiek kritizēta, jo īpaši par ilgo laiku, kas nepieciešams, lai OLAF sniegtu informāciju valstu prokuroriem. Dažas dalībvalstis ierobežo sadarbību ar ārpustiesas struktūrām, piemēram, OLAF, pamatojoties uz noteikumiem par tiesas noslēpumu [5].

2013. gada 17. jūlijā Eiropas Komisija nāca klajā ar priekšlikumu izstrādāt Eiropas Padomes regulu par Eiropas Prokuratūras izveidi [4, 5]. Par šo jautājumu joprojām notiek diskusijas Eiropas Savienības Padomē.

Eiropas Prokuratūras juridiskais pamats un izveides noteikumi ir izklāstīti Līguma par Eiropas Savienības darbību 86. pantā, kurā ir noteikts [13]: "[..] lai apkarotu noziegumus, kas skar Savienības finansiālās intereses, Padome, pieṇemot regulas saskaṇā ar ipašu likumdošanas procedūru, var no Eurojust izveidot Eiropas Prokuratūru."

Saskaṇā ar Līguma par Eiropas Savienības darbību 86. panta 1. punktu Eiropas Prokuratūru izveido no Eirojust. Tiek plānots izveidot stingru saikni starp šìm abām organizācijām, pateicoties efektīvai sadarbībai un informācijas, zināšanu un resursu apmaiṇai. İpaši svarīgs aspekts ir tas, ka gan Eiropas Prokuratūrai, gan Eirojust ir jāpiedalās to lietu izmeklēšanā, kurās aizdomās turētās personas ir iesaistītas noziedzīgos nodarījumos, kas skar Eiropas Savienības finanšu intereses, kā arī citu noziedzīgu nodarījumu gadījumā. Tas nozīmē, ka būs nepieciešama nepārtraukta cieša sadarbība. Šis regulējums ir ietverts gan regulā par Eiropas Prokuratūru, gan regulā par Eirojust. Turklāt gadỉjumos, kad saistībā ar kādu jaukta rakstura lietu pilnvaras pārklājas, Eirojust var palīdzēt noteikt jurisdikciju [6]. 
Tiek plānots, ka Eirojust nodrošinās administratīva atbalsta pakalpojumus Eiropas Prokuratūrai tādās jomās kā personāls, finanses un informācijas tehnolog̣ijas. Piemēram, Eiropas Prokuratūra savām darba vajadzībām varēs izmantot Eirojust informācijas tehnologiju infrastruktūru, tostarp tās lietu uzskaites sistēmu, pagaidu darba datnes un rādītāju. Šĩ sadarbība tiks precizēta līgumā starp Eiropas Prokuratūru un Eirojust [6].

Tiek plānots, ka Eiropas Prokuratūras izveides gadījumā tās kompetencē būs OLAF pašreizējais pienākums veikt izmeklēšanu krāpniecības un citu pārkāpumu gadījumā, ja ir apdraudētas ES finansiālās intereses. Savukārt OLAF turpinās veikt administratīvās izmeklēšanas tādu pārkāpumu gadījumā, kas skar ES finansiālās intereses un kuros nav aizdomas par kriminālu rīcību. Tas arī turpinās izmeklēt smagus ES iestāžu darbinieku amatpārkāpumus, kas nav saistīti ar ES finansēm $[4,5]$.

Eiropas Prokuratūras izveides pievienotā vērtība galvenokārt ir saistāma ar kriminālvajāšanu skaita pieaugumu par noziegumiem, kas apdraud Eiropas Savienības finansiāāās intereses. Eiropas Prokuratūras izveide varētu uzlabot resursu izmantošanu un informācijas apmaiņu, kas nepieciešama sekmīgai izmeklēšanai un saukšanai pie kriminālatbildības par attiecīgo noziedzīgo nodarījumu. Savukārt tas varētu nostiprināt tiesībaizsardzības iestāžu reakciju uz šiem noziedzịgajiem nodarỉjumiem un paaugstināt preventīvo darbỉbu pret potenciālajiem noziedzniekiem. Eiropas Prokuratūra varētu apvienot izmeklēšanas un kriminālvajāšanas resursus atbilstīgi konkrētās situācijas vajadzībām, tādējādi padarot tiesībaizsardzību efektīvāku visas Eiropas un atsevišḳu valstu līmenī [6].

Eiropas Prokuratūra vadīs izmeklēšanu un kriminālvajāšanu dalībvalstīs, nodrošinās efektīvu izmeklēšanas un kriminālvajāšanas koordināciju un risinās problēmas, kas ir saistītas ar dažādo tiesību sistēmu piemērošanas jautājumiem. Pašreizējā sistēma, kurā dalībvalstis ir vienīgās atbildīgās par šādu izmeklěšanu un kriminālvajāšanu, ko atbalsta Eurojust un Eiropols, nav pietiekami efektīva, lai risinātu attiecīgos liela apmēra noziegumus un ar tiem saistīto kaitējuma problēmu.

Eiropas Prokuratūru sākotnēji bija plānots izveidot 2015. gadā, bet, ņemot vērā, ka par šo priekšlikumu joprojām ir aktīvas diskusijas, reālas darbības varētu tikt sāktas tuvākajos gados. Sagaidāms, ka pēc Eiropas Prokuratūras izveidošanas samazināsies krāpšana ar ES budžeta līdzekḷiem, kas saskaṇā ar Eiropas Komisijas 2016. gada 14. jūlija pretkorupcijas ziņojumu Eiropas Savienības dalībvalstīm ik gadu rada aptuveni 500 miljonu eiro lielus zaudējumus.

\section{Secinājumi}

1. Iestādēm, kurām ir dažāda teritoriālā un funkcionālā piekritỉba, ir dalìta atbildība, tāpēc tām ir daudz problēmu un ierobežojumu saistībā ar koordināciju, sadarbību un informācijas apmaiṇu. Nepilnības tiesas iestāžu rīcībā, vēršoties pret krāpšanu, ir novērojamas katru dienu dažādos līmeṇos un dažādām iestādēm, un tās ir arī galvenais škēerslis efektīvai izmeklēšanai un saukšanai pie atbildības par noziedzīgiem nodarījumiem, kas apdraud Eiropas Savienības finansiālās intereses. 
2. Saskaṇā ar Eiropas Komisijas 2016. gada 14. jūlija pretkorupcijas ziṇojumu Eiropas Savienības dalībvalstis, kas efektīvi vēršas pret korupciju savā valstī, bieži saskaras ar problēmām saistībā ar savu uzṇēmumu rīcību ārvalstīs, īpaši tajās, kur koruptīvas darbības ir plaši izplatītas.

3. Viens no labās prakses piemēriem, kā vērsties pret iekšzemes un ārvalstu kukuḷošanu, ir Apvienotās Karalistes 2010. gada likums par kukuḷošanu (UK Bribery Act).

4. Pateicoties Apvienotās Karalistes likumam par kukulıšanu, kurš stājās spēkā 2011. gada 1. jūlijā, Apvienotajai Karalistei pašlaik ir vieni no stingrākajiem noteikumiem pasaulē cinnā pret kukuḷošanu. Minētais likums paredz kriminālatbildību ne vien personām par kukuḷdošanu un kukuḷnemšanu un ārvalstu amatpersonu piekukuḷošanu, bet arī komerciālām organizācijām, kuras nenovērš kukulıšanu, kas izdarìta to vārdā.

5. Noteikumi par ekstrateritoriālu jurisdikciju lauj Liela apmēra krāpšanu apkarošanas birojam (SFO) saukt pie atbildības jebkuru uzñēmumu vai personu, kura atrodas Apvienotajā Karalistē, pat tad, ja uzṇēmums ir bāzēts ārvalstīs. Komerciālās organizācijas tiek atbrīvotas no kriminālatbildības, ja tām bijušas atbilstīgas procedūras kukuḷošanas novēršanai.

6. Eiropas Prokuratūras izveides pievienotā vērtība galvenokārt ir saistāma ar kriminālvajāšanu skaita pieaugumu par noziegumiem, kas apdraud Eiropas Savienības finansiālās intereses. Eiropas Prokuratūras izveide varētu uzlabot resursu izmantošanu un informācijas apmaiṇu, kas nepieciešama sekmīgai izmeklēšanai un saukšanai pie kriminālatbildības par attiecīgo noziedzīgo nodarījumu. Savukārt tas varētu nostiprināt tiesībaizsardzības iestāžu reakciju uz šiem noziedzịgajiem nodarījumiem un paaugstināt preventīvo darbību pret potenciālajiem noziedzniekiem. Eiropas Prokuratūra varētu apvienot izmeklēšanas un kriminālvajāšanas resursus atbilstīgi konkrētās situācijas vajadzībām, tādējādi padarot efektīvāku tiesībaizsardzỉbu Eiropas Savienības un valstu līmenī.

7. Krāpšana Eiropas Savienības dalībvalstīs varētu tikt samazināta, ja Eiropas Prokuratūra vadīs izmeklēšanu un kriminālvajāšanu dalībvalstīs, nodrošinās efektīvu izmeklēšanas un kriminālvajāšanas koordināciju un risinās problēmas, kas saistītas ar dažādo tiesību sistēmu piemērošanas jautājumiem. Pašreizējā sistēma, kurā dalïbvalstis ir vienīgās atbildīgās par šādu izmeklēšanu un kriminālvajāšanu, ko atbalsta Eurojust un Eiropols, nav pietiekami efektīva, lai risinātu liela apmēra noziegumus un ar tiem saistīto kaitējuma problēmu. 


\section{Transnational Fraud: International Legal Cooperation Modernisation Problems}

\section{Abstract}

International legal cooperation with foreign investigation authorities is very important, including all types of it, including abroad located witness hearing, required information gathering, help faster completion of criminal prosecution for submission to court. Even if all required databases and possibilities to acquire information are available in Latvia, without international legal cooperation it is not possible to find and testimony witnesses, as well as seize bank accounts.

Considering current economic problems within Europe and outside, it is necessary to have stronger guarantees for public expenditure integrity and transparency. Citizens of the European Union member states expect from the European Union authorities considerable action to help the member states to protect legal economy against organised crime, financial and tax fraud, legalisation of illegal funds and corruption. Cross-border fraud cases require coordinated and effective European Union level investigation and criminal prosecution; however, current information exchange and coordination level is not sufficient to reach this goal, despite enforced efforts of Eirojust, Eiropol and The European Anti-Fraud Office (OLAF).

Keywords: fraud, corruption, European Union, legal cooperation.

\section{Literatūra}

1. Apvienoto Nāciju Organizācijas pretkorupcijas konvencija. Latvijas Vēstnesis. 191 (3349), 30.11.2005.

2. Asongu, S. A. 2014. Globalization, (fighting) corruption and development: how are these phenomena linearly and nonlinearly related in wealth effects? Journal of Economic Studies, 41 (3), 346-369. doi.org/10.1108/JES-04-2012-0048.

3. Badinger, H., Nindl, E. Globalization, Inequality, and Corruption. Vienna University of Economics and Business, Department of Economics, April 2012. Iegūts no: https://epub.wu.ac. at/3521/1/wp139.pdf [sk. 26.02.2017.].

4. Eiropas Ekonomikas un sociālo lietu komitejas Nodarbinātîbas, sociālo lietu un pilsoniskuma specializētās nodaḷas atzinums par tematu "Priekšlikums Padomes regulai, ar ko izveido Eiropas Prokuratūru”. Brisele, 28.11.2013. COM (2013) 534, SOC/491.

5. Eiropas Komisija. Priekšlikums Padomes Regulai par Eiropas Prokuratūras izveidi. Eiropas Komisija. Brisele, 17.07.2013. COM (2013) 534, 2013/0255 (APP).

6. Eiropas Komisija. Informatīvs paziñojums par Eiropas Prokuratūras izveidi. Brisele, 17.07.2013. COM (2013) 534, 2013/0255 (APP).

7. Eiropas Komisijas ziṇojums Padomei un Eiropas Parlamentam, ES Pretkorupcijas zinnojums. Iegūts no: http://eur-lex.europa.eu/legal-content/LV/TXT/?uri=CELEX\%3A52014DC0038 [sk. 26.02.2017.]. 
8. Eiropas Savienības finanšu interešu aizsardzība - cīṇa pret krāpšanu. 2015. gada ziṇojums. Eiropas Komisijas ziņojums Parlamentam un Padomei. Brisele, 14.07.2016. COM (2016) 472.

9. Eiropas Tiesiskās sadarbības tīkls krimināllietās. [Eiropas e-tiesiskuma portāls.] Iegūts no: https://e-justice.europa.eu/content_ejn_in_criminal_matters-22-lv.do [sk. 26.02.2017.].

10. Konvencija par cīnu pret korupciju, kurā iesaistītas Eiropas Kopienas amatpersonas vai Eiropas Savienības dalībvalstu amatpersonas, kas izstrādāta, pamatojoties uz Līguma par Eiropas Savienību K 3. panta 2. punkta "c" apakšpunktu. Latvijas Vēstnesis. 69, 01.05.2004. Iegūts no: https:// likumi.lv/.../88027-par-konvenciju-par-cinu-pret-korupciju-kura-iesaistitas-eiro... [sk. 26.02.2017.].

11. Krimināltiesību pretkorupcijas konvencija. Latvijas Vēstnesis. 460/464 (2371/2375), 20.12.2000. Iegūts no: https://www.vestnesis.lv/ta/id/13807-kriminaltiesibu-pretkorupcijas-konvencija [sk. 26.02.2017.].

12. Krutova, E. Starpvalstu sadarbība transnacionālo organizèto noziegumu izmeklēšanā: monogräfija. Zin. red. A. Kavalieris. Rīga: Ērika Krutova.

13. Līgums par Eiropas Savienības darbību. Eiropas Savienības Oficiālais Vēstnesis. C326/01. Iegūts no: https:/www.ecb.europa.eu/ecb/legal/pdf/c_32620121026lv.pdf [sk. 26.02.2017.].

14. Pārskats par korupcijas apkarošanu. Mācību vadlīnijas uzṇēmumiem, kuri sadarbojas ar Abbott. Iegūts no: http://dam.abbott.com/en-us/documents/pdfs/transparency/actg_latvian.pdf [sk. 26.02.2017.].

15. The Bribery ACT 2010. Guidance about procedures which relevant commercial organizations can put into place to prevent persons associated with them from bribing (section 9 of the Bribery Act 2010). Ministry of Justice, UK. Iegūts no: https://www.justice.gov.uk/downloads/.../briberyact-2010-guidance.pdf [sk. 26.02.2017.].

16. UK Bribery Act. Iegūts no: http://www.legislation.gov.uk/ukpga/2010/23/contents [sk. 26.02.2017.].

17. Vatikāna dokuments par korupcijas cēloṇiem un sekām. [Vatikāna Radio.] Iegūts no: http:// lv.radiovaticana.va/storico/2006/10/06/vatik\%C4\%81na_dokuments_par_korupcijas_c\%C4\%931o\%C5\%86iem_un_sek\%C4\%81m/let-98196 [sk. 26.02.2017.].

18. Wilkinson, P. The 2010 UK Bribery ACT Adequate Procedures. Guidance on good practice procedures for corporate anti-bribery programmes. Transparecy International UK. July, 2010. 